\title{
ANALISIS FAKTOR DETERMINAN STATUS GIZI IBU HAMIL DI MOMBYKIDS JOMBANG
}

\author{
Analysis Factor Determinant Of Nutritional Status Of Pregnant Women In Mombykids \\ Jombang
}

Baroroh Barir, SKM., M.Gz

1. D3 Kebidanan STIKes ICMe Jombang

\section{Riwayat artikel}

Diajukan: Agustus 2020

Diterima: September 2020

\section{PenulisKorespondensi: \\ - Baroroh Barir, SKM, M.Gz \\ - D3 Kebidanan STIKes ICMe Jombang \\ - barorohbarir5@gmail. com}

\section{Kata Kunci:}

Faktor Determinan, Ibu Hamil, Status Gizi

\section{Pendahuluan}

Status gizi merupakan faktor penting pada masa kehamilan yang berpengaruh terhadap kesehatan ibu hamil, perkembangan embrio dan janin. Masa kehamilan merupakan suatu proses yang berkesinambungan sehingga membutuhkan satus gizi cukup untuk menghindari
Masalah kesehatan ibu hamil khususnya status gizi dengan determinan faktor yang berpengaruh menjadi penting untuk dikaji karena berpengaruh terhadap outcome kehamilan.Usia, pengetahuan, dukungan suami dan kunjungan ANC berpengaruh terhadap status gizi ibu hamil.Tujuan penelitian adalah menganalisis faktor determinan status gizi ibu hamil di mombykids Jombang.Penelitian merupakan penelitian kuantitatif dengan desain cros sectional. Variabel independen adalah usia, pengetahuan, dukungan suami dan kunjungan ANC. Variabel dependen adalah status gizi ibu hamil. Jumlah sampel adalah $30 \mathrm{ibu}$ hamil dengan pengambilan sampel secara purposive sampling. Hasil penelitian dilakukan analisis univariat, bivariat dan multivariat menggunakan uji statistik regresi logistik. Hasil penelitian menunjukkan bahwa faktor determinan status gizi ibu hamil adalah usia $(\mathrm{OR}=4,18$, CI $95 \%=1,77-2,433$, p-value $=0,023)$, pengetahuan $(\mathrm{OR}=3,28$, CI 95\% $=1,28-5,60$, $\mathrm{p}$-value $=0,034)$, dukungan suami $(\mathrm{OR}=$ $3,72$, CI 95\%=1,49-1,14, p-value $=0,028)$ dan kunjungan ANC (OR= 4,57, CI 95\%= $1,28-7,24$, p-value $=0,038$ ). Kesimpulan penelitian ini adalah faktor determinan status gizi ibu hamil adalah usia, pengetahuan, dukungan suami dan kunjungan ANC sehingga diharapkan ibu dapat meningkatkan status gizi dengan memperhatikan faktor determinan status gizi ibu hamil.

The health problem of pregnant women, especially the fulfillment of nutritional status with the determinant of influential factors becomes important to be examined because it affects the outcome of pregnancy. Age, knowledge, husband's support and visit to the ANC affect the nutritional status of pregnant women. The aims of the research isto analyse the factors determinant of the nutritional status of pregnant women in mombykids Jombang. Research is a quantitative study with the Cros sectional design. Independent variables are age, knowledge, husband support and the ANC visits. Dependent variables are the nutritional status of expectant mothers. The sample number is 30 pregnant mothers with purposive sampling. The results of the research conducted univariate analysis, bivariate and multivariate using logistic regression statistical tests. The results showed that the determinant of the nutritional status factor of pregnant women is age $(O R=4,18, C I 95 \%=1,77-2,433$, $p$-value $=0,023)$, knowledge $(O R=3,28$, CI 95\% $=1,28-5,60, p$-value $=0,034)$, husband support $(O R=3,72, C I$ 95\% $=1,49-1,14$, $p$-value $=0,028)$ and visits ANC $(O R=4,57, C I$ 95\% = 1,28-7,24, $p$-value $=0,038)$. Conclusion of this research is a factor determinant of the nutritional status of pregnant women is age, knowledge, husband support and visit ANC so that mothers are expected to increase the status of nutrition by paying attention to factors determinant of the nutritional status of pregnant women.

defisiensi gizi yang berdampak pada kesehatan ibu dan bayi (Azizah and Adriani, 2018).Wanita hamil sangat rentan terhadap kekurangan gizi, pemenuhan vitamin dan mineral dibutuhkan untuk meningkatkan status gizi ibu hamil terkait pemenuhan kebutuhan metabolik janin agar dapat tumbuh dan berkembang secara optimal. 
Diperkirakan bahwa $38,2 \%$ dari wanita hamil (usia 15-49 tahun) di seluruh dunia dengan status gizi kurang dan menyebabkan terjadinya anemia. Kekurangan vitamin dan mineral pada kehamilan dikaitkan dengan hasil kesehatan yang merugikan baik pada ibu dan neonatal.Penatalaksanaan masalah status gizi khusunya status gizi pada wanita hamil untuk mendukung upaya mencapai tujuan SDG's (Sustainable Development Goals), selain itu sebagai upaya untuk pencapaian stategi global yang ditetapkan melalui rencana implementasi yang komprehensif pada nutrisi ibu dan bayi sampai remaja 2016-2030(WHO, 2016).

Hasil Riskesdas 2018 menunjukkan bahwa proporsi ibu hamil yang mendapatkan PMT (Pendamping Makanan Tambahan) pada tahun 2018 adalah 89,7\% sehingga diharapkan status gizi ibu hamildapat meningkat. Anemia dapat disebabkan karena status gizi yang rendah, diketahui $73,2 \%$ ibu hamil yang mendapatkan tablet tambah darah dengan $26,8 \%$ yang tidak mendapatkan tablet tambah darah dengan kejadian anemia yang mengalami peningkatan yaitu $37,1 \%$ pada tahun 2013 meningkat menjadi 48,9\% pada tahun 2018(Kemenkes RI dan BPP, 2018), dengan demikin dibutuhkan upaya yang komprehensif untuk meningkatkan kesehatan ibu hamil salah satunya dengan menjaga status gizi ibu hamil untuk mencegah anemia dan dampak keterlambatan pertumbuhan dan perkembangan pada bayi. Asupan gizi ibu hamil bermanfaat untuk ibu dan bayinya sehingga membutuhkan penatalaksanaan yang komprehensif (Chen et al., 2016).

Masalah status gizi ibu dan anak, meliputi mal nutrisi dan kelebihan berat badan yang menjadimasalah global dengan konsekuensi penting untuk kelangsungan hidup ibu dan bayi, insiden penyakit akut dan kronis, perkembangan yang terganggu dan dapat menurunkan produktivitas ekonomi baik individu ataupun masyarakat karena gangguan kesehatan(Black et al., 2013). Masalah status gizi ibu hamil dapat berdampak yang buruk terhadap bayinya mulai dari BBLR (Berat Badan Lahir Rendah), PJT (Pertumbuhan Janin Terhambat), kurus, pendek, kurus, daya tahan tubuh rendah serta risiko meninggal dunia(Alfarisi, Nurmalasari and Nabilla, 2019). Kelahiran prematur dan anemia juga dikaitkan sebagai salah satu dampak kekurangan gizi selama masa kehamilan (Martin, Sotres-Alvarez and Siega-Riz, 2015).

Faktor determinan status gizi ibu hamil salah satunya adalah faktor demografis yaitu usia, tingkat pendidikan, status perkawinan berkaitan dengan dukungan suami, parietas dan status sosial ekomoni serta kunjungan ANC khusunya pada awal kehamilan dan frekuensi kunjungan ANC yang sesuai. Usia reproduktif yaitu 20-35 tahun berhubungan dengan kemampuan tubuh untuk menyerap nutrisi dalam tubuh secara optimal sehingga ibu hamil dapat memiliki status gizi yang baik dan bermanfaat bagi bayi untuk pemenuhan nutrisi (Ogundipe et al., 2012). Status gizi ibu hamil juga dikaitkan dengan pengetahuan ibu, pengetahuan terkait nutrisi ibu hamil menjadi salah satu faktor yang berpengaruh terhadap status gizi ibu hamil, salah satu cara yang dapat dilakukan untuk meningkatkan pengetahuan dengan mengikuti kegiatan penyuluhan kesehatan ibu hamil sehingga ibu tahu terkait nutrisi yang baik sebelum dan sesudah kehamilan(Lecorguillé et al., 2020).Berdasarkan uraian latar belakang diatas peneliti tertarik untuk penelitian tentang analisis faktor determinan status gizi ibu hamil di momby kids Jombang.

\section{Metodologi}

Penelitian adalah penelitian kuantitatif yang menggunakan desain crossectional di mombykids Jombang. Variabel terikat adalah status gizi ibu hamil.Usia, pengetahuan, dukungan suami dan kunjungan ANC adalah variabel bebas, dengan populasinya seluruh ibu hamil yang berkunjung di mombykids Jombang. Sampel penelitian sebanyak 30 ibu hamil, sampel penelitian yang dipilih secara purposive 
sampling. Data diambil pada bulan Maret sampai April tahun 2020 dengan menggunakan kuesioner.Data yang terkumpul kemudian dianalisis menggunakan uji satatistik regresi logistik.

\section{Hasil dan Pembahasan HASIL}

Pendidikan ibu sebagian besar adalah tinggi sebanyak 16 subjek penelitian $(53,3 \%)$. Sebagian besar ibu memiliki pekerjaan sebanyak 19 subjek penelitian (63,3\%). Karakteristik terakhir adalah pendapatan, sebagian besar ibu memiliki pendapatan tinggi sebanyak 17 subjek penelitian $(56,7 \%)$.

Tabel 1Distribusi Frekuensi Karakteristik Penelitian

\begin{tabular}{clcc}
\hline No. & Karakteristik & F & \% \\
\hline 1. & Pendidikan & & \\
& Rendah & 14 & 46,7 \\
& Tinggi & 16 & 53,3 \\
2. & Pekerjaan & & \\
& Tidak bekerja & 11 & 36,7 \\
& Bekerja & 19 & 63,3 \\
3. & Pendapatan & & \\
& Rendah & 13 & 43,3 \\
& Tinggi & 17 & 56,7 \\
\hline
\end{tabular}

Sumber: Data Primer, 2020

Tabel 2 Distribusi Frekuensi Variabel Penelitian

\begin{tabular}{clcc}
\hline No. & Karakteristik & F & \% \\
\hline 1. & Usia & & \\
& $<20->35$ tahun & 15 & 50,0 \\
$\quad$ 20-35 tahun & 15 & 50,0 \\
2. & Pengetahuan & & \\
& Rendah & 17 & 56,7 \\
& Tinggi & 13 & 43,3 \\
3. & Dukungan & & \\
& suami & & \\
& Lemah & 16 & 53,3 \\
& Kuat & 14 & 46,7 \\
4. Kunjungan & & \\
& ANC & & 50,0 \\
& Tidak aktif & 15 & 50,0 \\
& Aktif & 15 & \\
5. Status gizi & & 36,7 \\
& Tidak normal & 11 & 63,3 \\
& Normal & 19 &
\end{tabular}

Sumber: Data Primer, 2020

Berdasarkan tabel 2 distribusi frekuensi variabel penelitian yang terdiri dari usiadijadikan data dikotomi yaitu $<20$ tahun- > 35 tahun dan 20-35 tahun, pengetahuan dijadikan data dikotomi yaitu rendah dan tinggi, dukungan suamiyang dijadikan data dikotomi yaitu lemah dan kuat, kunjungan ANC dijadikan data dikotomi yaitu tidak aktif dan aktif dan status gizidijadikan data dikotomi yaitu normal dan tidak normal. Hasil penelitian menunjukkan bahwa setengahnya dari seluruh subjek penelitian memiliki usia $<20$ tahun $->35$ tahun yaitu sebanyak 15 subjek penelitian atau sebesar 50,0\%. Variabel pengetahuan sebagian besar adalah rendah yaitu sebanyak 17 atau sebesar $56,7 \%$. Sebagian besar ibu memiliki dukungan suami yang lemah yaitu sebanyak 16 atau sebesar 53,3\%. Kunjungan ANC subjek penelitian setengahnya adalah aktif yaitu sebanyak 15 subjek penelitian atau sebesar $50 \%$.Variabel yang terakhir yaitu status gizi ibu hamil yaitu sebagian besar normal sebanyak 19 subjek penelitian sebesar $63,3 \%$.

Tabel 2 Analisis Faktor Determinan Status Gizi Ibu Hamil

\begin{tabular}{clcc}
\hline No. & Variabel & OR & p-value \\
\hline 1. & Usia & 4,18 & 0,023 \\
2. & Pengetahuan & 3,27 & 0,034 \\
3. & $\begin{array}{l}\text { Dukungan } \\
\text { suami }\end{array}$ & 3,72 & 0,028 \\
& Kunjungan & 4,57 & 0,038 \\
\hline
\end{tabular}

Sumber: Data Primer, 2020

Hasil uji regresi logistik menunjukkan bahwa usia berpengaruh terhadap status gizi ibu hamil $(\mathrm{OR}=4,18, p$-value $=0,023)$ berarti ibu dengan usia 20-35 tahun kemungkinan 4,18 kali lebih besar memiliki status gizi yang normal daripada ibu berusia $<20$ tahun - > 35 tahun, pengetahuan berpengaruh terhadap status gizi ibu hamil $(\mathrm{OR}=3,27, p$ value $=0,034)$ berarti ibu dengan pengetahuan yang tinggi kemungkinan 3,27 kali lebih besar memiliki status gizi normal 
daripada ibu dengan pengetahuan rendah, dukungan suami berpengaruh terhadap status gizi ibu hamil $(\mathrm{OR}=3,72, p$-value $=$ 0,028 ) berarti ibu dengan dukungan suami yang kuat kemungkinan 3,72 kali lebih besar memiliki status gizi yang normal daripada ibu dengan dukungan suami yang lemah. Variabel yang terakhir adalah kunjungan ANC yangberpengaruh terhadap status gizi ibu hamil $(\mathrm{OR}=4,57, p$-value $=0,038)$ berarti ibu dengan kunjungan ANC yng aktif kemungkinan 4,57 kali lebih besar memiliki status gizi yang normal daripada ibu yang tidak aktif kunjungan ANC.

\section{PEMBAHASAN}

1. Pengaruh usia terhadap status gizi ibu hamil

Hasil penelitian menunjukkan bahwa usia merupakan salah satu faktor determinan status gizi ibu hamil. Penelitian yang dilakukan oleh Ernawati (2018) dengan hasil yang sejalan yaitu terdapat pengaruh usia $<20$ atau $>35$ tahun untuk mengalami KEK (Kekurangan Energi Kronis) dibandingkan dengan ibu yang berusia 20-35 tahun dan secara statistik signifikan.Usia ibu yang < 20 tahun dan $>35$ tahuncenderung mengalami masalah gizi. Ibu yang berusia $<20$ tahuan pada proses fisiologis tubuh membutuhkan asupan yang cukup untuk kebutuhan metabolisme tubuh yang lebih banyak untuk masa pertumbuhan dibandingkan dengan ibu yang berusia 20-35 tahun, sehingga apabila terjadi kehamilan maka akan terjadi kompetitif pemenuhan kebutuhan zat gizi antara ibu dan bayi(Mahirawati, 2014).

Ibu hamil yang berusia > 35 tahun mayoritas memiliki masalah kesehatan seperti penyakit kronik hipertensi, diabetes dan lainnya yang dapat menghambat masuknya zat gizi untuk pemenuhan kebutuhan bayi melalui plasenta selain itu di usia > 35 tahun organ organ tubuh mengalami penurunan fungsi yang semakin melemah oleh karena terjadinya proses penuaan sehingga apabila terjadi kehamilan dibutuhkan lebih banyak nutrisi daripada ibu yang berusia 20-35 tahun karena berada dalam rentang usia yang sehat untuk reproduktif (Yana, Musafaah and Yulidasari, 2016).

2. Pengaruh pengetahuan terhadap status gizi ibu hamil

Hasil penelitian menunjukkan bahwa pengetahuan menjadi faktor determinan status gizi ibu hamil.Penelitian Popa et al. (2013) sejalan dengan hasil penelitian terkait pengetahuan yang dapat mempengaruhi status gizi ibu hamil dengan nilai $\mathrm{OR}=$ 4,7 berarti ibu dengan pengetahuan yang tinggi terkait nutrisi ibu hamil kemungkinan 4,7 kali lebih besar untuk memiliki status gizi yang normal daripada ibu dengan pengetahuan rendah. Ibu hamil adalah kelompok yang rentan terhadap gangguan gizi karena selama masa kehamilankebutuhan akanzat gizi meningkat. Upaya peningkatkan pengetahuan ibu hamil tentang nutrisi selama masa kehamilan merupakan bentuk intervensi yang dilakukan sehingga dapat menurunkan angka kejadian mal nutrisi pada ibu hamil(Ravaoarisoa et al., 2018). Perkembangan seorang anak bergantung sepenuhnya pada status gizi ibu selama kehidupan janin dan enam bulan pertama kehidupan sehingga dibutuhkan penatalaksanaan yang komprehensif.Kelasibu hamil dapat diberikan sebagai intervensi, dengan memberikan konseling untuk meningkatkan pengetahuan ibu (Masonetal., 2013).

Pengetahuan gizi berhubungan dengan status gizi ibu hamil karena dengan pengetahuan yang tinggi terkait nutrisi ibu hamil dapat meningkatkan kemampuan dan ketrampilan ibu dalam menentukan dan mengolah makanan yang sehat selain itu pengetahuan terkait zat gizi yang baik untuk pertumbuhan dan perkembangan bayi khususnya 
untuk nutrisi otak bayi sangat penting untuk diberikan untuk generasi mendatang yang lebih baik(Pendleton, Saunders and Shlafer, 2020). Kebutuhan zat gizi selama kehamilan meningkat sesuai kebutuhan biologimasa kehamilan.Status gizi perempuan sebelum dan selama kehamilan memainkan peranan penting dalam menentukan proses perkembangan awal janin dan kesehatan ibu. Pengetahuan tentang suplemen gizi salah satunya tentang manfaat suplementasi asam folat secara signifikan mengurangi risiko cacat pada janin (Ramakrishnan et al., 2012).Dengan demikian pengetahuan tentang manfaat gizi selama masa kehamilan sangat penting untuk diketahui ibu hamil.

3. Pengaruh dukungan suami terhadap status gizi ibu hamil

Hasil penelitian menunjukkan bahwa dukungan suami adalah faktor determinan status gizi pada ibu hamil.Dukungan suami dapat diberikan berupa dukungan untuk mengkonsumsi suplemen diet dan makanan untuk ibu hamil yang bermaanfaat untuk pasokan nutrisi yang memadai bagi ibu dan janin.Dukungan finansial, informatif dan material dapat diberikan kepada ibu hamil.Keluarga khususnya suami, keluarga, teman sebaya dan tenaga kesehatan dapat memberikan dukungan kepada ibu hamil. Hasil penelitian sejalan dengan penelitian Sudirman, Puspitawati and Muflikhati (2019)yang menunjukkan bahwa dukungan suami memiliki pengaruh yang terhadap status gizi ibu hamil karena dengan adanya dukungan yang kuat dari suami dapat meningkatkan kesejahteraan ibu baik selama proses kehamilan ataupun setelah melahirkan. Suami yang dapat memberikan dukungan yang kuat menurunkan risiko terjadinya kecemasan selama masa kehamilan.

Diani and Susilawati (2013)juga menjelaskan bahwa ibu dengan dukungan suami yang lemah memiliki kecemasan yang sedang dan tinggi dibandingkan dengan ibu yang memiliki dukungan kuat, hal tersebut menunjukkan bahwa dukungan suami memiliki eranan yang penting dalam keluarga untuk meningkatkan sataus gizi ibu hamil.Dukungan suami terhadap ibu hamil untuk melakukan pemeriksaan rutin kesehatan juga berpengaruh terhadap status gizi ibu hamil. Pemeriksaan yang dilakukan salah satunya sebagai upaya deteksi dini masalah kesehatan yang mungkin dapat terjadi selama kehamilan sehingga menurunkan risiko masalah status gizi ibu hamil (Bahramian et al., 2018).

4. Pengaruh kunjungan ANC terhadap status gizi ibu hamil

Hasil penelitian menunjukkan bahwa kunjungan ANC merupakan salah satu faktor determinan staus gizi.Kumendong et al. (2015)menjelaskan bahwa kunjungan ANC berpengaruh terhadap status gizi ibu hamil.Pengetahuan ibu dapat meningkatkan melalui konseling pada kunjungan ANC terkait nutrisi yang baik untuk ibu hamil serta deteksi dini masalah kehamilan yang mungkin terjadi.Manfaat dilakukan kunjungan ANC salah satunya mendapatkan pendidikan gizi melalui konseling pada saat kunjungan, konseling yang diberikan terkait nutrisi yang baik selama masa kehamilan sehingga diharapkan dapat menurunkan angka kejadian mal nutrisi selama masa kehamilan.

Nnam (2015)menjelaskan bahwa nutrisi memainkan peran penting dalam mengurangi beberapa risiko kesehatan yang terkait dengan kehamilan seperti risiko kematian janin dan bayi, retardasi pertumbuhan intra rahim, BBLR dan kelahiran prematur, penurunan cacat lahir, kretinisme, perkembangan otak yang buruk dan risiko infeksi. Wanita hamil membutuhkan diet bervariasi dan 
meningkatkan asupan gizi untuk mengatasi kebutuhan ekstra selama kehamilan.Konseling pada kunjungan ANC harus menjadi salah satu komponen inti dalam pelayanan kesehatan di klinik kesehatan ibu dan anak dengan memberikan pendidikan nutrisi ibu hamil agar status gizi ibu normal.Petugaskesehatan harus menggunakan kesempatan kunjungan ANC untuk memberikan pendidikan gizi tentang diet yang tepat untuk wanita hamil sebagai upaya pencegahan terjadinya masalah kesehatan pada ibu hamil.

Konseling wanita hamil adalah langkah pertama untuk perencanaan pendidikan kesehatan dan berdampak positif terhadap status gizi ibu pada masa kehamilan.Konseling gizi yang diberikan diharapkan dapat menambah pengetahuan ibu khususnya tentang diet untuk ibu hamil, praktek diet serta kebutuhan gizi. Kunjungan ANC yang aktif dan didukung pemberian konseling nutrisi yang baik diharapkan dapat mengubah pengetahuan, sikap, dan perilaku seorang ibu hamil terkait nutrisi ibu hamil sehingga meningkatkan status gizi ibu hamil (Demilew, Alene and Belachew, 2020).

\section{Simpulan}

Usia, pengetahuan, dukungan suami dan kunjungan ANC merupakan faktor determinan status gizi ibu hamil. Berdasarkan hasil uji statistik yang dilakukan kunjungan ANC memiliki nilai OR yang lebih besar dibandingkan dengan variabel usia, pengetahuan dan dukungan suami. Ibu dengan kunjungan ANC yang aktif memiliki kemungkinan 4,57 untuk memiliki status gizi yang normal dibandingkan ibu yang tidak aktif melakukan kunjungan ANC.

\section{Daftar Pustaka}

Alfarisi, R., Nurmalasari, Y. and Nabilla, S. (2019). Status gizi ibu hamil dapat menyebabkan kejadian stunting pada balita, Jurnal Kebidanan Malahayati, 5(3): 271-278. doi: 10.33024/jkm.v5i3.1404.

Azizah, A. and Adriani, M. (2018). Tingkat kecukupan energi protein pada ibu hamil trimester pertama dan kejadian Kekurangan Energi Kronis, Media Gizi Indonesia, 12(1): 21. doi: 10.20473/mgi.v12i1.21-26.

Bahramian, H., Mohebbi, S. Z. and Quinonez, R. B. (2018). Qualitative exploration of barriers and facilitators of dental service utilization of pregnant women: A triangulation approach', BMC Pregnancy and Childbirth, 18(1): 1-11. doi: 10.1186/s12884-0181773-6.

Black, R. E., Victora, C. G., Pwalker, S., Bhutta, Z. A., Chistian, P., et al. (2013). Maternal and child undernutrition and overweight in lowincome and middle-income countries', The Lancet, 382(9890): 427-451. doi: 10.1016/S0140-6736(13)60937-X.

Chen, X., Zhao, D., Mao, X., Xia, Y. and Zhang, H. (2016). Maternal dietary patterns and pregnancy outcome. Nutrients, 8: 1-26. doi: 10.3390/nu8060351.

Demilew, Y. M., Alene, G. D. and Belachew, T. (2020). Effect of guided counseling on dietary practices of pregnant women in West Gojjam Zone, Ethiopia', PLoS ONE. Nutrition Journal, 15(5):1-12. doi: 10.1371/journal.pone.0233429.

Diani, L. P. P. and Susilawati, L. K. P. A. (2013). Pengaruh dukungan suami terhadap istri yang mengalami kecemasan pada kehamilan trimester ketiga di Kabupaten Gianyar, Jurnal Psikologi Udayana, 1(1): 1-11. doi: 10.24843/jpu.2013.v01.i01.p01.

Ernawati, A. (2018). Hubungan usia dan status pekerjaan ibu dengan kejadian Kurang Energi Kronik, XIV(1): 27-37.

Kementerian Kesehatan RI Badan Penelitian 
dan Pengembangan (2018). Hasil Utama Riset Kesehatan Dasar, Kementrian Kesehatan Republik Indonesia, 1: 27-37.

Kumendong, L. G., Kundre, R. and Bataha, Y. (2015). Hubungan frekuensi kunjungan Antenatal Care (ANC) dan status gizi ibu hamil trimester III dengan Berat Badan Lahir Rendah (BBLR) bayi di RSU Pancaran Kasih Manado tahun 2015.Jurnal Keperawatan, 53(9): 1689-1699. doi: 10.1017/CBO9781107415324.004.

Lecorguillé, M., Lioret, S., Lauzon-Guillain, B., de Gavelle, E., Forhan, A.et al. (2020) 'Association between dietary intake of one-carbon metabolism nutrients in the year before pregnancy and birth anthropometry', Nutrients, 12(3). doi: 10.3390/nu12030838.

Mahirawati, V. K. (2014). Faktor-faktor yang berhubungan dengan Kekurangan Energi Kronik (KEK) pada ibu hamil di Kecamatan Kamoning dan Tambelangan, Kabupaten Sampang, Jawa Timur. 17(2):193-202.

Martin, C. L., Sotres-Alvarez, D. and SiegaRiz, A. M. (2015). Maternal dietary patterns during the second trimester are associated with preterm birth.The Journal of Nutrition, 145(8): 18571864. doi: 10.3945/jn.115.212019.

Mason, J. B., Shrimpton, R., Saldanha, L. S., Ramakrishnan, U., Victoria, C. G. et al. (2013). The first 500 days of life: policies to support maternal nutrition. Global Health Action, 1: 25-33. doi: 10.1007/978-1-908517-90-6_3.

Nnam, N. M. (2015). Improving maternal nutrition for better pregnancy outcomes.Proceedings of the Nutrition Society, 74(4): 454-459. doi: $10.1017 / \mathrm{S} 0029665115002396$.

Ogundipe, O., Hoyo, C., Ostbye, T., Oneko, O., Manongi, R.et al. (2012). Factors associated with prenatal folic acid and iron supplementation among 21,889 pregnant women in Northern Tanzania: A cross-sectional hospitalbased study', BMC Public Health, 12(1): 1. doi: 10.1186/1471-2458-12481.

Pendleton, V., Saunders, J. B. and Shlafer, R. (2020). Corrections officers' knowledge and perspectives of maternal and child health policies and programs for pregnant women in prison. Health and Justice. Health \& Justice, $\quad 8(1)$ : 1-12. doi: 10.1186/s40352-019-0102-0.

Popa, A. D., Nita, O., Graur, L. I., Popescu, R. M., Botnariu, G. E.et al. (2013). Nutritional knowledge as a determinant of vitamin and mineral supplementation during pregnancy.BMC Public Health, 13(1): 1-10. doi: 10.1186/1471-2458-131105.

Ramakrishnan, U., Grant, F., Goldenberg, T., Zongrone, A. and Martorell, R. (2012). Effect of women's nutrition before and during early pregnancy on maternal and infant outcomes: A systematic review.Paediatric and Perinatal Epidemiology, 26(1): 285301. doi: $10.1111 /$ j.13653016.2012.01281.x.

Ravaoarisoa, L., Randriamanantsaina, L., Rakotonirina, J., Donnen, P. and Dramaix, M. W. (2018). Socioeconomic determinants of malnutrition among mothers in the Amoron'i Mania region of Madagascar: a cross-sectional study', BMC Nutrition, 4(1): 1-8. doi: 10.1186/s40795-018-0212-4.

Sudirman, S., Puspitawati, H. and Muflikhati, I. (2019). Peran suami dalam menentukan kesejahteraan subjektif istri pada saat hamil dan melahirkan.Jurnal Ilmu Keluarga dan Konsumen, 12(1): 26-37. doi: 10.24156/jikk.2019.12.1.26.

World Health Organization (2016). WHO 
guideline: use of multiple micronutrient powders for point-of-use fortification of foods consumed by pregnant women. WHO Press: 26. Available at: www.who.int/about/licensing/.

Yana, Musafaah and Yulidasari, F. (2016). Hubungan antara usia ibu pada saat hamil dan status anemia dengan Kejadian Berat Badan Lahir Rendah (BBLR).Jurnal Publikasi Kesehatan Masyarakat, 3(1): 2025. 